This item was submitted to Loughborough's Research Repository by the author.

Items in Figshare are protected by copyright, with all rights reserved, unless otherwise indicated.

\title{
The first study about the relationship between the extractability of thiacalix[4]arene derivatives and the position of the coordination binding sites
}

PLEASE CITE THE PUBLISHED VERSION

http://dx.doi.org/10.1039/C4OB02393E

\section{PUBLISHER}

(C) The Royal Society of Chemistry

\section{VERSION}

AM (Accepted Manuscript)

\section{PUBLISHER STATEMENT}

This work is made available according to the conditions of the Creative Commons Attribution-NonCommercialNoDerivatives 4.0 International (CC BY-NC-ND 4.0) licence. Full details of this licence are available at: https://creativecommons.org/licenses/by-nc-nd/4.0/

\section{LICENCE}

CC BY-NC-ND 4.0

\section{REPOSITORY RECORD}

Zhao, Jiang-Lin, Hirotsugu Tomiyasu, Xin-Long Ni, Xi Zeng, Mark R.J. Elsegood, Carl Redshaw, Shofiur Rahman, P.E. Georghiou, Simon J. Teat, and Takehiko Yamato. 2019. "The First Study About the Relationship Between the Extractability of Thiacalix[4]arene Derivatives and the Position of the Coordination Binding Sites". figshare. https://hdl.handle.net/2134/18137. 


\section{Organic \& Biomolecular Chemistry}

1

The first study about the relationship between the extractability of thiacalix[4]arene derivatives and the position of the coordination binding sites

Jiang-Lin Zhao, Hirotsugu Tomiyasu, Xin-Long Ni, Xi Zeng, Mark R. J. Elsegood, Carl Redshaw,

Shofiur Rahman, Paris E. Georghiou and

Takehiko Yamato*

The extractability of thiacalix[4]arene derivatives $\mathbf{2 - 4}$ are largely dependent on the position of the binding sites.

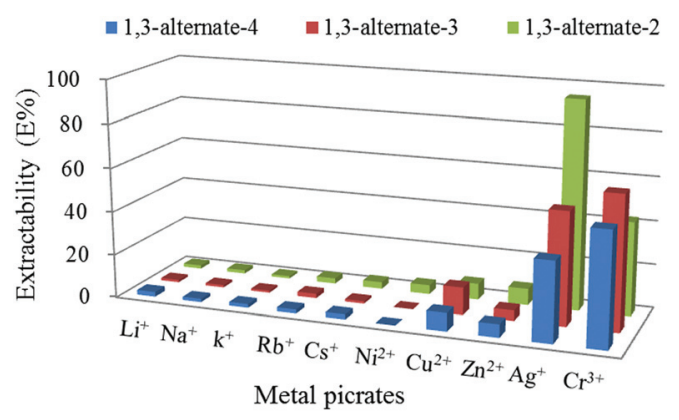

Please check this proof carefully. Our staff will not read it in detail after you have returned it.

Translation errors between word-processor files and typesetting systems can occur so the whole proof needs to be read. Please pay particular attention to: tabulated material; equations; numerical data; figures and graphics; and references. If you have not already indicated the corresponding author(s) please mark their name(s) with an asterisk. Please e-mail a list of corrections or the PDF with electronic notes attached - do not change the text within the PDF file or send a revised manuscript. Corrections at this stage should be minor and not involve extensive changes. All corrections must be sent at the same time.

Please bear in mind that minor layout improvements, e.g. in line breaking, table widths and graphic placement, are routinely applied to the final version.

We will publish articles on the web as soon as possible after receiving your corrections; no late corrections will be made.

Please return your final corrections, where possible within $\mathbf{4 8}$ hours of receipt, by e-mail to: obcarsc.org 


\section{Queries for the attention of the authors}

\section{Journal: Organic \& Biomolecular Chemistry}

Paper: c4ob02393e

Title: The first study about the relationship between the extractability of thiacalix[4]arene derivatives and the position of the coordination binding sites

Editor's queries are marked like this [Q1, Q2,...], and for your convenience line numbers are indicated like this $[5,10,15, \ldots]$.

Please ensure that all queries are answered when returning your proof corrections so that publication of your article is not delayed.

\begin{tabular}{|c|c|c|}
\hline $\begin{array}{l}\text { Query } \\
\text { Reference }\end{array}$ & Query & Remarks \\
\hline Q1 & $\begin{array}{l}\text { For your information: You can cite this article before you } \\
\text { receive notification of the page numbers by using the following } \\
\text { format: (authors), Org. Biomol. Chem., (year), DOI: 10.1039/ } \\
\text { c4ob02393e. }\end{array}$ & \\
\hline Q2 & Please check that the inserted CCDC number is correct. & \\
\hline Q3 & $\begin{array}{l}\text { Please carefully check the spelling of all author names. This is } \\
\text { important for the correct indexing and future citation of your } \\
\text { article. No late corrections can be made. }\end{array}$ & \\
\hline Q4 & $\begin{array}{l}\text { In Scheme 1, is it correct that the solvent is shown as } \\
\text { "DMF\&THF"? Or should it perhaps be shown as "DMF-THF" as it } \\
\text { appears in the text? If the latter, please resupply the scheme, } \\
\text { either as ChemDraw file or as TIF at } 600 \text { dpi. }\end{array}$ & \\
\hline Q5 & $\begin{array}{l}\text { Please check that the changes to the English in the sentence } \\
\text { beginning "This maybe attribute that when } 3 \text { complexes with } \\
\mathrm{Ag}+, \ldots \text {... have not affected the meaning. }\end{array}$ & \\
\hline
\end{tabular}


Three organic ionophores (2-4) based on the p-tert-butylthiacalix[4]arene backbone, blocked in the 1,3alternate conformation, bearing two pyridyl coordinating moieties (ortho for $\mathbf{2}$, meta for $\mathbf{3}$ and para for $\mathbf{4}$ ), have been synthesized and characterized in the solid state. The solvent extraction experiments with the metal ions showed that the ability of these derivatives to complex with $\mathrm{Ag}^{+}$appeared to be largely dependent on the position of the nitrogen atoms of the pyridyl ring. Two different complexation modes have been confirmed by ${ }^{1} \mathrm{H}$ NMR titration, ionophore 2 armed with two pyridyl moieties, complexed with $\mathrm{Ag}^{+}$ cation through $\mathrm{N} \ldots \mathrm{Ag}^{+} \ldots \mathrm{S}$ interactions; however, ionophore 3 and ionophore 4, complexed with $\mathrm{Ag}^{+}$ through metal-nitrogen $\left(\mathrm{N} \cdots \mathrm{Ag}^{+}\right)$interactions. The DFT computational studies were consistent with the experimental findings. These findings will provide us an important rule to design an appropriate thiacalix-

Received 13th November 2014, Accepted 21st January 2015 DOI: 10.1039/c4ob02393e www.rsc.org/obc arene ionophore in the future. Another study on the possibility for application of ionophores 2-4 for the treatment of waste water containing $\mathrm{Cr}(\mathrm{VI})$ and $\mathrm{Cr}(\mathrm{III})$, showed that ionophore $\mathbf{3}$ was useful in the application of the solvent extraction method in selective treatment of waste water containing $\mathrm{Cr}(\mathrm{VI})$ and $\mathrm{Cr}(\mathrm{III})$ prior to discharge.

\section{Introduction}

Thiacalix[4]arene is widely used as a macrocyclic platform for designing and building synthetic receptors toward metal cations. ${ }^{1}$ The complexation properties of these molecules appear to be highly dependent upon the nature and number of donor atoms and also the conformation of the calix $[n]$ arene moiety. ${ }^{2}$ It is found that thiacalix[4]arene has a very high ability to bind transition metal ions, ${ }^{3}$ which has been quite unexpected considering the poor binding ability of calix[4]arene. The 1,3-alternate stereoisomer, which shows an allosteric effect in metal cation binding, or offers divergently

\footnotetext{
${ }^{a}$ Department of Applied Chemistry, Faculty of Science and Engineering, Saga University, Honjo-machi 1, Saga 840-8502, Japan. E-mail: yamatot@cc.saga-u.ac.jp ${ }^{b}$ Department Key Laboratory of Macrocyclic and Supramolecular Chemistry of Guizhou Province, Guizhou University, Guiyang, Guizhou 550025, China ${ }^{c}$ Chemistry Department, Loughborough University, Loughborough, LE11 3TU, UK ${ }^{d}$ Department of Chemistry, The University of Hull, Cottingham Road, Hull, Yorkshire HU6 $7 R X, U K$

${ }^{e}$ Department of Chemistry, Memorial University of Newfoundland, St. John's, Newfoundland and Labrador, Canada A1B3X7

$\dagger$ Electronic supplementary information (ESI) available: Details of single-crystal X-ray crystallographic data. ${ }^{1} \mathrm{H},{ }^{13} \mathrm{C}$ NMR, MS and IR spectra of 3, computational study of 2-4 with $\mathrm{Ag}^{+}$. CCDC 1021161 . For ESI and crystallographic data in CIF or other electronic format see DOI: 10.1039/c4ob02393e
}

oriented binding sites, is of special interest. ${ }^{1,4}$ For the synthesis of macrocycles with controlled (switchable) binding sites of metal cations, ${ }^{5}$ there is a need for the development of novel approaches to the design of tetrasubstituted thiacalix[4]arenes with various groups with specific conformations. Recently, we reported the regioselective synthesis of distal-bis[(2-pyridylmethyl)oxy]tetrathiacalix[4]arene in the 1,3-alternate conformation by a protection-deprotection method using benzyl groups as protecting groups. ${ }^{6}$ Pyridine derivatives of thiacalix[4]arene can exist as positional isomers which differ by the positions of the nitrogen $(\mathrm{N})$ atom on the pyridyl unit which can be ortho, meta and para to the phenolic oxygen attachment position. The N-hetero atoms can serve as additional coordination sites due to their electron lone pairs and can also undergo facile further modifcation. Given that the position of the nitrogen atoms of the pyridyl ring can differ in thiacalix[4]arene derivatives, it is interesting to assess what kind of ability these derivatives will provide to interact with metal cations (hard or soft).

Chromium(III) has been reported to be biologically essential to mammals as it maintains effective glucose, lipid, and protein metabolisms. However, chromium(vi) can be toxic, as it can diffuse as $\mathrm{Cr}_{2} \mathrm{O}_{7}{ }^{2-}$ or $\mathrm{HCr}_{2} \mathrm{O}_{7}{ }^{-}$through cell membranes and oxidize biological molecules. ${ }^{7}$ Therefore, selective treatment of waste water containing $\mathrm{Cr}(\mathrm{VI})$ and $\mathrm{Cr}(\mathrm{III})$ prior to dis- 
charge is essential. Solvent extraction is one of the most commonly used treatment methods and employs a selective complexant especially for ions in aqueous solution. Thus, the development of efficient extractants for anions has received considerable attention in recent years. ${ }^{8}$ The dichromate $\left(\mathrm{Cr}_{2} \mathrm{O}_{4}{ }^{2-}\right.$ and $\left.\mathrm{HCr}_{2} \mathrm{O}_{7}{ }^{-}\right)$ions are anions with oxide functionalities at their periphery. These oxide moieties are potential sites for hydrogen bonding to the complexant or host molecule(s). Thiacalix[4]arene derivatives with nitrogen functionalities such as pyridine, amino, or imino groups on their lower rim have been shown to be capable of interacting with anions by hydrogen bonds as efficient extractants for oxoanions. ${ }^{9}$ Thus, the introduction of a pyridyl moiety to thiacalix[4]arene would potentially lead to an effective extractant for dichromate anions.

In this study, a series of 1,3-alternate thiacalix[4]arenes bearing pyridyl moieties (ortho, meta and para) at the lower rim which should have the appropriate encapsulating ionophilic cavity were targeted for synthesis. The relationship between the position of the nitrogen atoms of the pyridyl ring and the ability of these derivatives to interact with various ionic species were evaluated.

\section{Results and discussion}

The synthesis of the new thiacalix[4] arene derivatives is given

in Scheme 1. For the synthesis of thiacalix[4]arene derivatives based on different functional units (1,3-alternate-2, 1,3-alternate-3 and 1,3-alternate-4), the parent compound (distal-1) was prepared according to published literature procedures. ${ }^{6}$ The reaction of bisbenzylated compound distal-1 with 3-(chloromethyl)pyridine in THF-DMF in the presence of $\mathrm{Cs}_{2} \mathrm{CO}_{3}$ as base yielded 1,3-alternate-3 in 59\% yield. 1,3-alternate-2 and 1,3-alternate-4 were prepared as following a published procedure. ${ }^{6,10}$ All of the structures were confirmed by their ${ }^{1} \mathrm{H}$ and ${ }^{13} \mathrm{C}$ NMR and IR spectra, MS, elemental analyses and by X-ray crystallography.

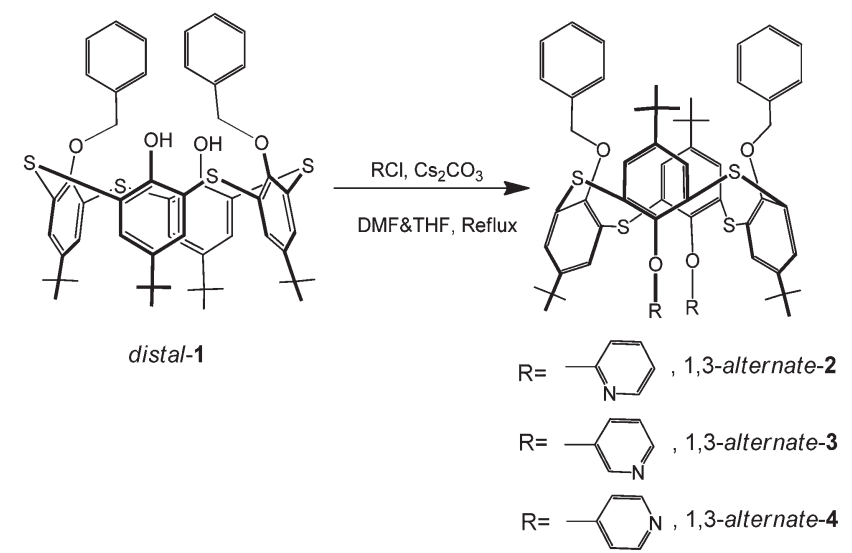

Scheme 1 O-Alkylation of distal-1 with (chloromethyl)pyridine in the presence of $\mathrm{Cs}_{2} \mathrm{CO}_{3}$.
The ${ }^{1} \mathrm{H}$ NMR spectrum of 1,3-alternate-3 shows two singlets for tert-butyl protons, in which both tert-butyl protons were observed at higher field, at $\delta 0.85$ and $0.86 \mathrm{ppm}$ due to the ring current effect arising from the two benzyl benzene rings and the two pyridine rings introduced; two singlets for the methylene protons at $\delta 5.06 \mathrm{ppm}\left(\mathrm{OCH}_{2}\right.$ Benzyl) and $5.19 \mathrm{ppm}$ $\left(\mathrm{OCH}_{2}\right.$ Pyridyl), respectively, indicating a $\mathrm{C}_{2}$-symmmetric structure for the 1,3-alternate-3 (Fig. S1 $\dagger$ ).

$\mathrm{X}$-ray quality colourless crystals of 1,3-alternate-2, and 1,3alternate-3 were obtained by recrystallizations from mixed $\mathrm{MeOH}$ and $\mathrm{CHCl}_{3}$ solutions. The single crystal X-ray diffraction Ortep (Pluto) representations of 2 and 3 are shown in Fig. 1. It is clear that these compounds adopt 1,3-alternate conformations. Interestingly, both of the pyridine nitrogen atoms in 2 are orientated outwards, the distance between them being $9.079 \AA$ A. However, the pyridine nitrogen atoms in 3 are orientated inwards, the distance between them being only $3.883 \AA$.

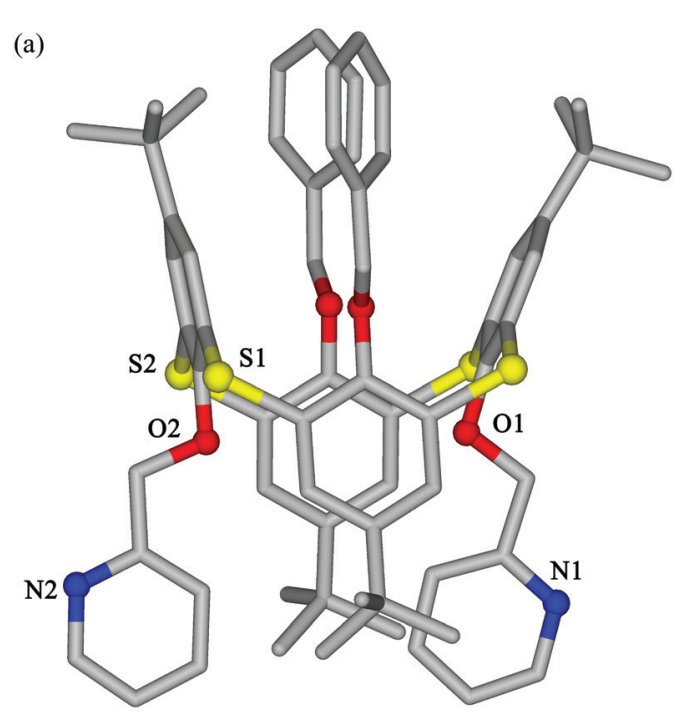

(b)

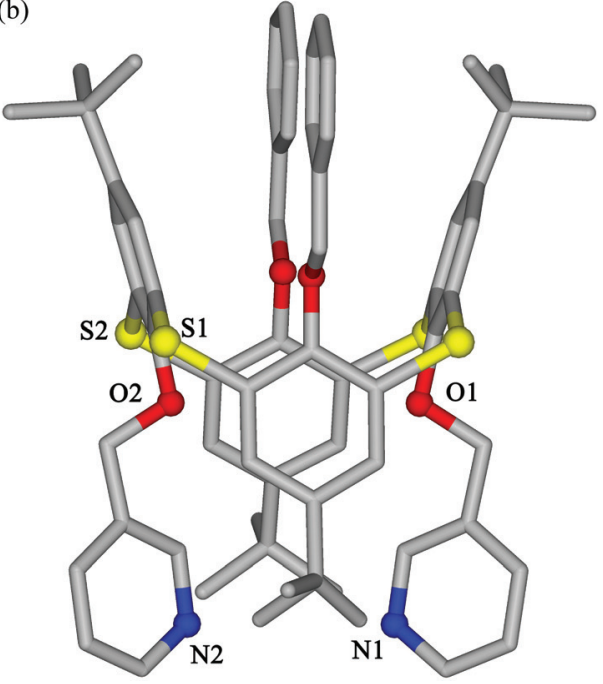

Fig. 1 X-ray structures of (a) $2^{6}$ and (b) 3 . Hydrogen atoms have been omitted for clarity. 
This may be attributed to the distances between the pyridine nitrogen atoms and the oxygen atoms ( $\mathrm{N} 1 \cdots \mathrm{O} 1$ and $\mathrm{N} 2 \cdots \mathrm{O} 2)$. In the case of compound 2 , the distances between $\mathrm{N} 1 \cdots \mathrm{O} 1$ and $\mathrm{N} 2 \cdots \mathrm{O} 2$ are shorter; but for 3 the corresponding $\mathrm{N} 1 \cdots \mathrm{O} 1$ and $\mathrm{N} 2 \cdots \mathrm{O} 2$ distances are longer.

The shorter distances and hence the stronger electron repulsion could therefore be factors which control the different orientations of the nitrogen atoms toward each other.

Recently, the synthesis of calix[4]arenes bearing pendant pyridine groups at the lower rim as potential ligands for transition metal cations have been reported. ${ }^{11} \mathrm{~A}$ similar investigation has also been conducted using hexahomotrioxacalix[3]arene and homocalix[3] arene-based derivatives. ${ }^{12}$ It is well known that the metal selectivity and extractability of these types of receptors are dependent on the ring size and the nature of the $O$-alkyl substituents. However, it is still unknown whether the metal extractability can be affected by the position of the coordination binding sites of the substituents themselves. Therefore, it is of importance to assess the relationship between the position of the nitrogen atoms of the pyridyl ring and the ability of these derivatives (2-4) to interact with ions. Experiments for solvent extraction of aqueous phase metal ions to the organic phase were therefore undertaken with 2-4. The results showed that the extraction of transition metals by all three receptors 2-4 was higher than for the extraction of alkali metals, especially for $\mathrm{Cr}^{3+}$ and $\mathrm{Ag}^{+}$(Fig. 2). The $E \%$ values of $\mathrm{Cr}^{3+}$ i.e. $43 \%, 61 \%$ and $52 \%$ for $2-4$, respectively, showed that a higher $\mathrm{Cr}^{3+}$ affinity exists for these molecules. However, what is surprising is that the extractability for $\mathrm{Ag}^{+}$, the $E \%$ values of $95 \%, 52 \%$ and $36 \%$ for $\mathbf{2 - 4}$, respectively, showed that the extractability of $\mathrm{Ag}^{+}$by 2 to 4 decreased gradually. These compounds are positional isomers differing only by the position of the nitrogen atom on the pyridyl ring. The position of the $\mathrm{N}$ atoms on the pyridyl rings (ortho for 2, meta for 3 and para for 4), which determines the distances between the nitrogen and the diaryl thiaether linkages were also reduced gradually. Recently, Ferlay reported a 1,3-alternate conformation thiacalix[4]arene armed with four pyridyl (ortho), complexed with $\mathrm{Ag}^{+}$cation through $\mathrm{N} \cdots \mathrm{Ag}^{+} \cdots \mathrm{S}$ interactions. ${ }^{13}$

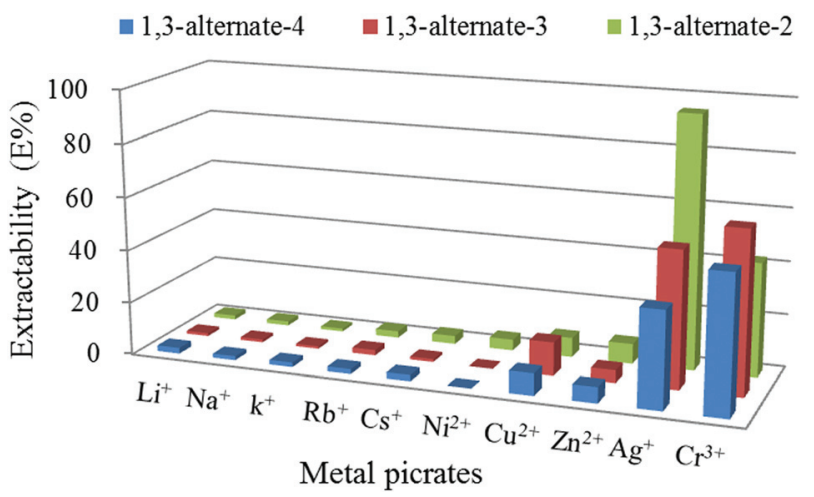

Fig. 2 Extraction percentages of metal picrates with ionophores 2-4 ([host] $=4.0 \times 10^{-5} \mathrm{M}$ in $\mathrm{CH}_{2} \mathrm{Cl}_{2}$, [guest $]=4.0 \times 10^{-5} \mathrm{M}$ in water at $\left.25^{\circ} \mathrm{C}\right)$.
Thus, the extractability $(E \%)$ of $\mathbf{2 - 4}$ which followed the order of $2>3>4$, may be attributed to the shorter distance, the stronger $\mathrm{N} \cdots \mathrm{Ag}^{+} \cdots \mathrm{S}$ interactions, the higher extractability $(E \%)$. This hypothesis is supported by the stability constants, which follow the same order of $2>3>4$. The binding constant $\left(K_{\mathrm{a}}\right)$ values for the complexation with $\mathrm{Ag}^{+}$ion was determined to be $2.05 \times 10^{4} \pm 875 \mathrm{M}^{-1}(2), 3.86 \times 10^{3} \pm 572 \mathrm{M}^{-1}$ (3), $2.25 \times 10^{3} \pm$ $365 \mathrm{M}^{-1}$ (4) based on the Benesi-Hildebrand equation, ${ }^{23}$ respectively (Fig. S13-18†).

Due to the existence of the two potential metal-binding sites, namely, the pyridine moieties and two benzyl moieties, there are several possibilities for metal complexation for compounds 2-4. Both 1:1 and 1:2 metal complexation might be possible, attributable to electrostatic interactions as well as cation $-\pi$ interactions. Job plots of $\mathbf{3}$ and $\mathbf{4}$ were carried out in the $\mathrm{H}_{2} \mathrm{O}-\mathrm{CH}_{2} \mathrm{Cl}_{2}$ phases. The $E \%$ values reach maxima at 0.5 mol fraction when 3 or $\mathbf{4}$ with $\mathrm{Ag}^{+}$are changed systematically (Fig. S12†). Similar $1: 1$ coordination of 2 with $\mathrm{Ag}^{+}$was shown by Job plots in our previous study (Fig. S12†). ${ }^{6}$ Thus, it can be concluded that $\mathrm{Ag}^{+}$forms $1: 1$ complexes with 2-4. These results suggest the major contribution of receptors 2-4 to $\mathrm{Ag}^{+}$binding are from the nitrogens of the pyridine rings, and not from the alternative cation- $\pi$-interactions.

Furthermore, in order to look further into the binding properties of receptors 2-4 with $\mathrm{Ag}^{+},{ }^{1} \mathrm{H}$ NMR titration experiments were carried out in $\mathrm{CD}_{3} \mathrm{Cl}-\mathrm{CD}_{3} \mathrm{CN}=10: 1$ solution. The chemical shift changes for compound 2-4 on complexation with $\mathrm{Ag}^{+}$are illustrated in Fig. 3 and are summarized in Fig. 4.

Significant changes were observed for the pyridine ring protons after the complexation of each of 2-4 with

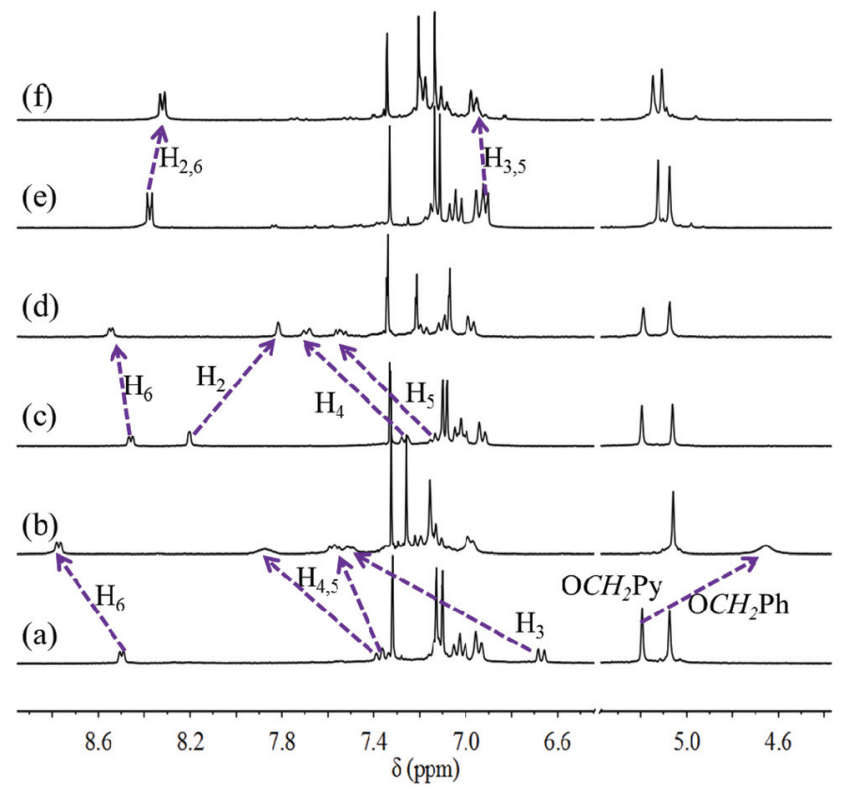

Fig. $3{ }^{1} \mathrm{H}$ NMR spectral changes of ionophores 2-4 $\left(5 \times 10^{-3} \mathrm{M}\right)$ on addition of $\mathrm{AgClO}_{4}\left(300 \mathrm{MHz}, \mathrm{CDCl}_{3}-\mathrm{CD}_{3} \mathrm{CN}=10: 1\right.$, [ionophores 2-4] $=5 \times 10^{-3} \mathrm{M}$ ). (a) Free 2; (b) 2 in the presence of 1.0 equiv. of $\mathrm{AgClO}_{4}$; (c) free 3; (d) 3 in the presence of 1.0 equiv. of $\mathrm{AgClO}_{4}$; (e) free 4; (f) 4 in the presence of 1.0 equiv. of $\mathrm{AgClO}_{4}$. 

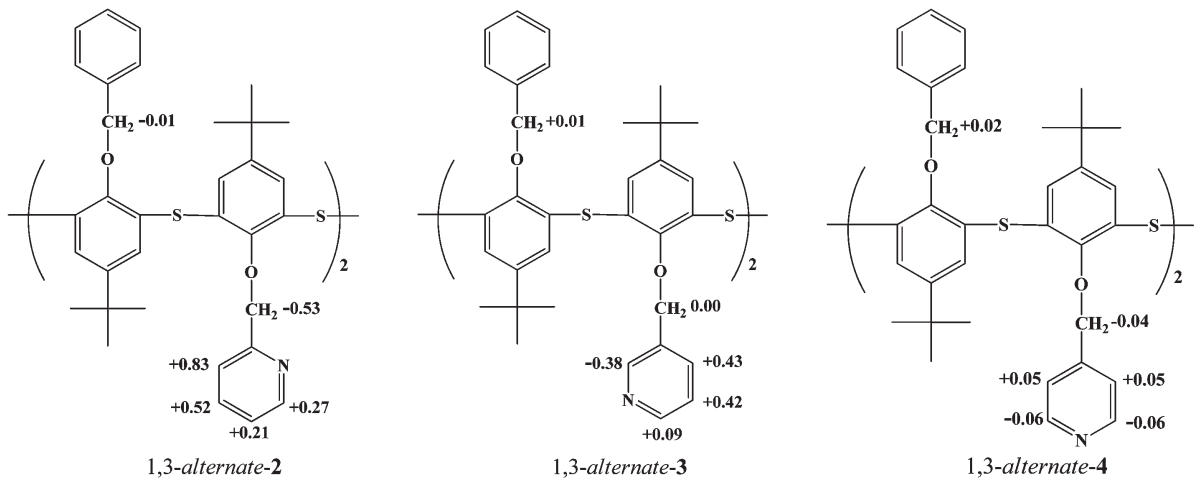

1,3-alternate-2

1,3-alternate-3

1,3-alternate-4

Fig. 4 Chemical shift changes of 2, 3 and 4 induced in the presence of $\mathrm{AgClO}_{4} ;+$ denotes the downfield and - denotes the upfield shift.

1.0 equiv. $\mathrm{Ag}^{+}$. In the case of 2 , the protons in the pyridine rings were shifted to lower field with $\Delta \delta=+0.27,+0.21,+0.52$ and +0.83 ppm for $\mathrm{H}_{6}, \mathrm{H}_{5}, \mathrm{H}_{4}$, and $\mathrm{H}_{3}$ protons, respectively. In contrast, the $\mathrm{OCH}_{2} \mathrm{Py}$ methylene protons were shifted dramatically up field, with $\Delta \delta=-0.53$. This may be due to both pyridine nitrogens of 2 close to the diaryl thiaether linkages $(\mathrm{N} 2 \cdots \mathrm{S} 1=$ $\mathrm{N} 2 \cdots \mathrm{S} 2=5.333 \AA$, Fig. 1a). Thus, when 2 complexes with $\mathrm{Ag}^{+}$, the $\mathrm{Ag}^{+}$is easily captured through $\mathrm{N} \cdots \mathrm{Ag}^{+} \cdots \mathrm{S}$ interactions. ${ }^{13}$ As a result, since the pyridine moieties are orientated inwards, the ring current shielding effect ${ }^{14}$ operating in the two thiacalixarene benzene rings is destroyed, forcing the steric conformation change. This affects the protons $\mathrm{H}_{6}, \mathrm{H}_{5}, \mathrm{H}_{4}$ and $\mathrm{H}_{3}$ of the pyridine rings which shift to lower field, due to the deshielding effect. Also, the $\mathrm{OCH}_{2}$ Py methylene protons become folded into the thiacalix[4]arene cavity and are thus shifted strongly upfield $(-0.53 \mathrm{ppm})$, due to the steric conformation changes.

However, a different phenomenon was observed in the complexation of 3 with $\mathrm{Ag}^{+}$. From the X-ray results, both pyridine nitrogen atoms in 3 were orientated inwards and far from the diaryl thiaether linkages $(\mathrm{N} 2 \cdots \mathrm{S} 1=6.360 \AA$ and $\mathrm{N} 2 \cdots \mathrm{S} 2=$ $5.847 \AA$, Fig. 1b), which is exactly opposite to what is seen with 2. The ${ }^{1} \mathrm{H}$ NMR spectrum of the $\mathrm{Ag}^{+}$of 3 reveals that the protons in the pyridine rings were shifted to lower field with $\Delta \delta=+0.09,+0.42$ and +0.43 ppm for $\mathrm{H}_{6}, \mathrm{H}_{5}$ and $\mathrm{H}_{4}$, protons, respectively. In contrast, a remarkable shielding effect experienced by proton $\mathrm{H}_{2}(-0.38 \mathrm{ppm})$ was observed. It may be that when 3 complexes with $\mathrm{Ag}^{+}$, the $\mathrm{Ag}^{+}$is trapped in the cavity formed by the nitrogen atoms in pyridine, and then the proton $\mathrm{H}_{2}$ end up folded into the $\pi$-cavity formed by the two thiacalixarene benzene rings and are thus shifted strongly upfield $(-0.38 \mathrm{ppm})$. Thus, 3 complexes $\mathrm{Ag}^{+}$through the metal-nitrogen interactions and therefore, due to the interaction of the nirogens and the $\mathrm{Ag}^{+}$, the $\mathrm{H}_{6}, \mathrm{H}_{5}$ and $\mathrm{H}_{4}$ protons of the pyridine rings shift to lower fields. ${ }^{15}$

Similar phenomena were observed for the complexation of 4 with $\mathrm{Ag}^{+}$; protons $\mathrm{H}_{3}$ and $\mathrm{H}_{5}$ in the pyridine rings of 4 shifted to lower field after complexation $(+0.05 \mathrm{ppm})$, as they are deshielded due to the $\mathrm{N} \cdots \mathrm{Ag}^{+}$interactions. Pyridine ring protons $\mathrm{H}_{2}$ and $\mathrm{H}_{6}$ in 4 shifted upfield after complexation
(-0.06 ppm), which may be attributed to the weaker repulsion between the nitrogen atoms in the pyridine rings. ${ }^{15}$

The chemical shift changes of the thiacalixarene benzene and benzyl protons may also be attributed to the conformational changes of 2-4 upon complexation. The chemical shift changes $(\Delta \delta)$ of 2-4 upon complexation are in the order 2 $>3>4$, which corresponds with the extractability of $\mathrm{Ag}^{+}$which was found to be in the same order.

To better understand the binding properties of receptors 2-4 with $\mathrm{Ag}^{+}$, a computation study was carried out. The molecular geometry of the individual structures in the gas-phase were fully optimized using Gaussian09, ${ }^{22}$ with the B3LYP level of DFT and the lanl2dz basis set. Significant conformational changes were observed for the pyridine ring protons of 2-4 after the complexation with $\mathrm{Ag}^{+}$. The conformation changes for 2 on complexation with $\mathrm{Ag}^{+}$ion can be seen in Fig. 5 (see the ESI for details of the computational study, Fig. S19-24†). Fig. 5 shows the structure (right) of the $2 \supset \mathrm{Ag}^{+}$complex. The optimized molecular geometry suggests that the $\mathrm{Ag}^{+}$binds, in accord with the ${ }^{1} \mathrm{H}$ NMR complexation study, via a $\mathrm{N} \cdots \mathrm{Ag}^{+} \cdots \mathrm{S}$ short contact distance bond, which results in the conformation change. The $\mathrm{N} \cdots \mathrm{N}$ distance between the pyridine ring nitrogens decreases from 8.001 to $3.761(\AA)$ since the nitrogen

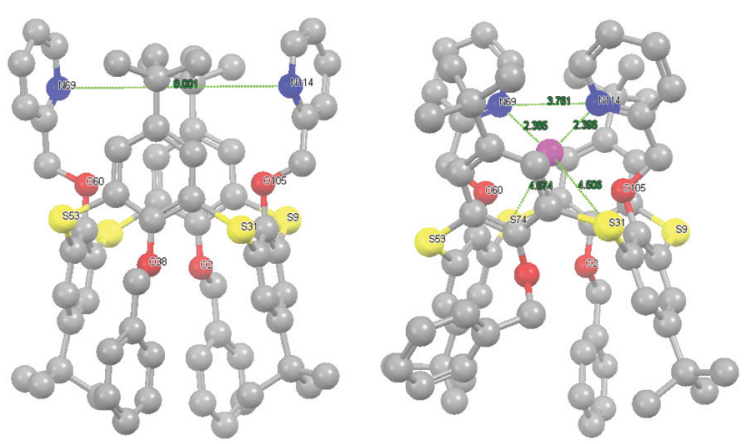

Fig. 5 Geometry-optimized (ball and stick) structures of: left: 2 and right: $2 \supset \mathrm{Ag}^{+}$complex. Color code for $\mathrm{Ag}^{+}=$magenta, pyridine nitrogen $=$ blue, sulphur $=$ yellow and oxygen atom $=$ red. Hydrogen atoms have been omitted for clarity. 
atoms move inwards after complexing with the $\mathrm{Ag}^{+}$. All four bridge sulphur atoms are roughly the same distance from the $\mathrm{Ag}^{+}$and presumably take an equal part in the coordination bonding.

However, a different phenomenon was observed in the complexation of 3-4 with $\mathrm{Ag}^{+}$. The $\mathrm{N} \cdots \mathrm{N}$ distance between the pyridine ring nitrogens decreases from 9.305 to 4.234 ( $\mathrm{\AA}$ ) for 3 and 10.138 to 3.798 (§) for 4 after complexing with the $\mathrm{Ag}^{+}$ (Fig. S19-S24, Table S1†). The optimized molecular geometry suggests that complexation of 3-4 with $\mathrm{Ag}^{+}$occurs via $\mathrm{N} \cdots \mathrm{Ag}^{+}$ interactions. The calculated complexation energies $(\Delta E \mathrm{~kJ}$ $\mathrm{mol}^{-1}$ ) of the $\mathrm{Ag}^{+}$complexes of 2-4 are $-488.096,-464.022$ and $-372.966 \mathrm{~kJ} \mathrm{~mol}^{-1}$ respectively (Table S2†), which is in agreement with the trend observed for the experimentally observed complexation data.

A preliminary evaluation of the anion binding efficiencies of $\mathbf{2 - 4}$ as potential extractants for the dichromate anion has been carried out by solvent extraction of aqueous solutions of $\mathrm{K}_{2} \mathrm{Cr}_{2} \mathrm{O}_{7}$ into dichloromethane at different $\mathrm{pH}$ values according to a reported procedure. ${ }^{15,16}$ The extraction results, summarized in Fig. 6, indicate that 3 showed to be more effective for the extraction of dichromate anions at low $\mathrm{pH}(\mathrm{pH} 1.5)$ than either 2 and $\mathbf{4}$. This is also consistent with the solvent extraction results seen with $\mathrm{Cr}^{3+}$ (Fig. 2). This could be attributed to the shorter (3.883 $\AA$ ) distances (Fig. 1) between the pyridine nitrogen atoms in 3 , which easily formed an efficient ionpair (hydrogen bonded) complex in the two-phase extraction system following proton transfer to the nitrogen atoms. As the $\mathrm{pH}$ of the solution increased from 1.5 to 2.5 to 5.5 to 7.0 , the $E \%$ for all three receptor ionophores decreased. This may directly be attributed to decreased proton concentrations in the solution. ${ }^{17}$ In other words, 3 showed a high extractability with dichromate anions only at lower $\mathrm{pH}$, but another high extractability of $\mathrm{Cr}^{3+}$ at higher $\mathrm{pH}$. Since, $\mathrm{Cr}(\mathrm{vI})$ is highly toxic, carcinogenic and harmful to human beings because it can diffuse as $\mathrm{Cr}_{2} \mathrm{O}_{7}{ }^{2-}$ or $\mathrm{HCr}_{2} \mathrm{O}_{7}^{-}$through cell membranes and oxidize biological molecules, ${ }^{7}$ whereas $\mathrm{Cr}(\mathrm{III})$ is an essential

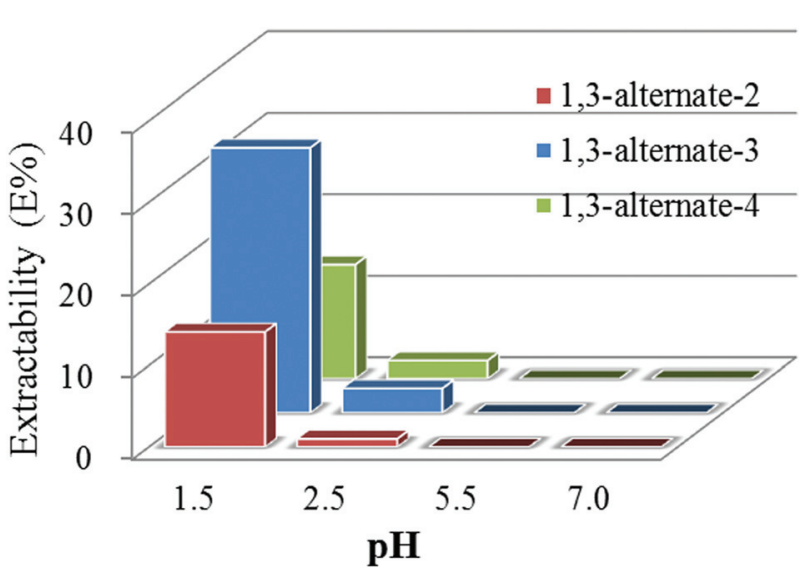

Fig. $6 E \%$ values of dichromate anion with ionophores 2-4 $(2.0 \times$ $10^{-4} \mathrm{M}, 2 \mathrm{~h}$ at $\left.25^{\circ} \mathrm{C}\right)$ at pH $1.5-7.0\left(\mathrm{H}_{2} \mathrm{O}-\mathrm{CH}_{2} \mathrm{Cl}_{2}: 10 / 10(\mathrm{v} / \mathrm{v}) ; \mathrm{K}_{2} \mathrm{Cr}_{2} \mathrm{O}_{7}=\right.$ $\left.1 \times 10^{-4} \mathrm{M}\right)$. ion for mammals as it maintains effective glucose, lipid, and protein metabolisms. ${ }^{18}$ Thus, 3 could be a meaningful extractant when applying a solvent extraction method for the selective treatment of waste water containing $\mathrm{Cr}(\mathrm{VI})$ and $\mathrm{Cr}(\mathrm{III})$ prior to discharge.

\section{Conclusion}

Three 1,3-alternate thiacalix[4]arenes bearing pyridyl moieties (ortho for $\mathbf{2}$, meta for $\mathbf{3}$ and para $\mathbf{4}$ ) at the lower rim were regioselectively synthesized. The solvent extraction experiments of the metal ions showed that the ability of these derivatives to complex with $\mathrm{Ag}^{+}(95 \%, 52 \%$ and $36 \%$ for 2,3 and 4 , respectively) appeared to be largely dependent on the position of the pyridine nitrogen atoms. The mode of binding of the $C_{2 \mathrm{~V}}$-symmetrical dipyridyl-substituted thiacalix[4]arenes, 2-4 with $\mathrm{Ag}^{+}$ was elucidated clearly using a ${ }^{1} \mathrm{H}$ NMR titration method. Two different complexation modes were observed: 2 armed with two ortho pyridyl groups, complexed with $\mathrm{Ag}^{+}$via $\mathrm{N} \cdots \mathrm{Ag}^{+} \cdots \mathrm{S}$ interactions, whereas 3 and 4 complexed with $\mathrm{Ag}^{+}$through $\mathrm{N} \cdots \mathrm{Ag}^{+}$interactions. The DFT computational studies were consistent with the experimental findings. These findings will provide us an important rule to design an appropriate thiacaixarene ionophore in the future.

Further studies aimed at the potential for application of these extractants for the treatment of waste water containing $\mathrm{Cr}(\mathrm{VI})$ and $\mathrm{Cr}(\mathrm{III})$ were initiated. The combination of the twophase solvent extraction data of $\mathrm{Cr}^{3+}$ and the results of the dichromate anion extraction by 3 , suggests that 3 could be useful in the application of a solvent extraction method for the selective treatment of waste water containing $\operatorname{Cr}(\mathrm{VI})$ and $\operatorname{Cr}(\mathrm{III})$ ions prior to discharge.

\section{Experimental section}

\section{General}

All melting points were determined using a Yanagimoto MP-S1. ${ }^{1} \mathrm{H}$ NMR spectra were determined at $300 \mathrm{MHz}$ with a Nippon Denshi JEOL FT-300 NMR spectrometer with $\mathrm{SiMe}_{4}$ as an internal reference; $J$ values are given in Hz. IR spectra were measured as $\mathrm{KBr}$ pellets or as liquid films on $\mathrm{NaCl}$ plates in a Nippon Denshi JIR-AQ2OM spectrophotometer. UV spectra were measured by a Shimadzu 240 spectrophotometer. Mass spectra were obtained on a Nippon Denshi JMS-01SG-2 mass spectrometer at an ionization energy of $70 \mathrm{eV}$ using a direct inlet system through GLC. Elemental analyses were performed by a Yanaco MT-5.

\section{Materials}

25,27-Dibenzyloxy-5,11,17,23-tetra-tert-butyl-2,8,14,20-tetrathiacalix[4]arene-26,28-diol (distal-1) was prepared from $5,11,17,23$-tetra-tert-butyl-2,8,14,20-tetrathiacalix[4]arene-25, $26,27,28$-tetraol in one step according to a reported procedure. ${ }^{6}$ 
O-Alkylation of distal-1 with 3-(chloromethyl)pyridine in the presence of $\mathrm{Cs}_{2} \mathrm{CO}_{3}$

A mixture of distal-1 (400 mg, $0.44 \mathrm{mmol})$ and $\mathrm{Cs}_{2} \mathrm{CO}_{3}(1.60 \mathrm{~g}$, $4.92 \mathrm{mmol}$ ) in dry tetrahydrofuran (THF; $8 \mathrm{~mL}$ ) was heated at reflux for $1 \mathrm{~h}$ under $\mathrm{N}_{2}$. A solution of 3-(chloromethyl)pyridine $(4.92 \mathrm{mmol})$ [prepared by neutralization of 3-(chloromethyl)pyridine hydrochloride (807 $\mathrm{mg}, 4.92 \mathrm{mmol}$ ) in DMF $(8 \mathrm{~mL})$ with a solution of triethylamine $(0.68 \mathrm{~mL}, 4.92 \mathrm{mmol})$ in THF $(8 \mathrm{~mL})$ at room temperature] was then added and the mixture heated at reflux for an additional $24 \mathrm{~h}$. After cooling the reaction mixture to room temperature, it was acidified with $1 \mathrm{M} \mathrm{HCl}(10 \mathrm{~mL})$ and extracted with $\mathrm{CH}_{2} \mathrm{Cl}_{2}$ $(100 \mathrm{~mL} \times 2)$. The combined extracts were washed with water $(50 \mathrm{~mL} \times 2)$, and dried $\left(\mathrm{MgSO}_{4}\right)$ and concentrated under reduced pressure to give a yellow oil. The residue was washed with methanol to give a mixture of tetra-O-alkylated products as a colorless precipitate. The precipitate was washed with ether $(5 \mathrm{~mL})$ to give a colourless solid. Recrystallization from $59 \%)$.

25,27-Dibenzyloxy-26,28-bis[(3-pyridylmethyl)oxy]-5,11,17,23tetra-tert-butyl-2,8,14,20-tetrathiacalix[4]arene (3). Colourless prisms $\left[\mathrm{MeOH}-\mathrm{CHCl}_{3}(1: 3)\right]$, m.p. 285.4-286.6 ${ }^{\circ} \mathrm{C}$. IR $\nu_{\max }$ $(\mathrm{KBr}) / \mathrm{cm}^{-1}: 3058,3030,2958,2902,2868,1575,1546$ and 1496. ${ }^{1} \mathrm{H}$ NMR $\left(400 \mathrm{MHz}, \mathrm{CDCl}_{3}\right) \delta=0.85(\mathrm{~s}, 18 \mathrm{H}, \mathrm{tBu}), 0.86(\mathrm{~s}$, $18 \mathrm{H}, \mathrm{tBu}), 5.06$ (s, $4 \mathrm{H}, \mathrm{Ar}-\mathrm{OCH}_{2} \mathrm{Ph}$ ), 5.19 (s, 4H, Ar-OCH $\mathrm{PH}_{2}$, $6.92(\mathrm{~d}, J=7.2 \mathrm{~Hz}, 4 \mathrm{H}, \mathrm{Ph}-H), 7.02(\mathrm{t}, J=7.6 \mathrm{~Hz}, 6 \mathrm{H}, \mathrm{Ph}-H)$, $7.07(\mathrm{~s}, 4 \mathrm{H}, \operatorname{Ar}-H), 7.10(\mathrm{~s}, 4 \mathrm{H}, \operatorname{Ar}-H), 7.12(\mathrm{t}, J=7.6 \mathrm{~Hz}, 2 \mathrm{H}$, $\left.\mathrm{Py}-H_{5}\right), 7.24\left(\mathrm{~d}, J=8.0 \mathrm{~Hz}, 2 \mathrm{H}, \mathrm{Py}-H_{4}\right), 8.22\left(\mathrm{~s}, 2 \mathrm{H}, \mathrm{Py}-H_{2}\right)$ and $8.46\left(\mathrm{~d}, J=4.8 \mathrm{~Hz}, 2 \mathrm{H}, \mathrm{Py}-H_{6}\right) \mathrm{ppm} .{ }^{13} \mathrm{C}$ NMR $(100 \mathrm{MHz}$, $\left.\mathrm{CDCl}_{3}\right) \delta=30.77,30.78,33.89,33.90,67.74,70.64,122.99$, $126.83,127.18,127.98,128.38,128.42,128.48,128.60,133.20$, $134.81,137.47,146.31,146.58,148.33,148.92,155.59$ and $156.61 \mathrm{ppm}$. FABMS: $\mathrm{m} / \mathrm{z}$ : $1083.30\left(\mathrm{M}^{+}\right)$. Anal. calcd for $\mathrm{C}_{66} \mathrm{H}_{70} \mathrm{~N}_{2} \mathrm{O}_{4} \mathrm{~S}_{4}$ (1083.53): C 73.16, H 6.51, N 2.59\%. Found: $\mathrm{C}$ 71.85, H 6.56, N 2.38\%.

Preparation of 25,27-dibenzyloxy-26,28-bis[(2-pyridylmethyl)oxy]-5,11,17,23-tetra-tert-butyl-2,8,14,20-tetrathiacalix[4]arene (2) was carried out following our previous report. ${ }^{6}$

25,27-Dibenzyloxy-26,28-bis[(2-pyridylmethyl)oxy]-5,11,17,23tetra-tert-butyl-2,8,14,20-tetrathiacalix[4]arene (2). Colourless

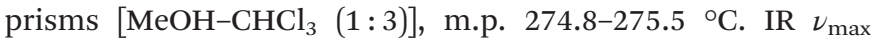
$(\mathrm{KBr}) / \mathrm{cm}^{-1}: 3058,3029,3008,2955,2901,2866,1571,1588$, 1546, 1496. ${ }^{1} \mathrm{H}$ NMR $\left(400 \mathrm{MHz}, \mathrm{CDCl}_{3}\right) \delta=0.83(\mathrm{~s}, 18 \mathrm{H}, \mathrm{tBu})$, $0.85(\mathrm{~s}, 18 \mathrm{H}, \mathrm{tBu}), 5.07\left(\mathrm{~s}, 4 \mathrm{H}, \mathrm{Ar}-\mathrm{OCH}_{2} \mathrm{Ph}\right), 5.20(\mathrm{~s}, 4 \mathrm{H}$, $\left.\mathrm{Ar}-\mathrm{OCH}_{2} \mathrm{Py}\right), 6.66$ (d, $\left.J=7.2 \mathrm{~Hz}, 2 \mathrm{H}, \mathrm{Py}-H_{3}\right), 6.94(\mathrm{~d}, J=7.0 \mathrm{~Hz}$, $4 \mathrm{H}, \mathrm{Ph}-H), 7.02(\mathrm{t}, J=7.5 \mathrm{~Hz}, 6 \mathrm{H}, \mathrm{Ph}-H), 7.09(4 \mathrm{H}, \mathrm{s}, \mathrm{Ar}-H)$, $7.12(4 \mathrm{H}, \mathrm{s}, \mathrm{Ar}-H), 7.35\left(\mathrm{t}, J=6.9 \mathrm{~Hz}, 4 \mathrm{H}, \mathrm{Py}-H_{4,5}\right)$ and $8.49(\mathrm{~d}$, $\left.J=4.8 \mathrm{~Hz}, 2 \mathrm{H}, \mathrm{Py}-H_{6}\right)$ ppm. ${ }^{13} \mathrm{C}$ NMR $\left(100 \mathrm{MHz}, \mathrm{CDCl}_{3}\right) \delta=$ $30.73,30.82$, 30.88, 33.88, 70.65, 71.46, 121.99, 126.80, 127.19, $127.99,128.23,128.60,128.71,137.52,146.15,146.35,148.33$, $156.01,156.67$ and $157.70 \mathrm{ppm}$.

Preparation of 25,27-dibenzyloxy-26,28-bis[(4-pyridylmethyl)oxy]-5,11,17,23-tetra-tert-butyl-2,8,14,20-tetrathiacalix[4]arene (4) was carried out following our previous report. ${ }^{10}$

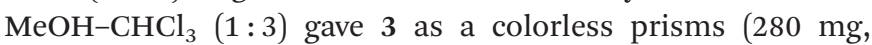

25,27-Dibenzyloxy-26,28-bis[(4-pyridylmethyl)oxy]-5,11,17,23tetra-tert-butyl-2,8,14,20-tetrathiacalix[4]arene (4). Colourless prisms $\left[\mathrm{MeOH}-\mathrm{CHCl}_{3}(1: 3)\right]$, m.p. $283-285{ }^{\circ} \mathrm{C}$. IR $\nu_{\max }(\mathrm{KBr}) /$ $\mathrm{cm}^{-1}: 3055,3029,2952,2921,2853,1604,1572,1562 .{ }^{1} \mathrm{H}$ NMR $\left(400 \mathrm{MHz}, \mathrm{CDCl}_{3}\right) \delta=0.84(\mathrm{~s}, 18 \mathrm{H}, \mathrm{tBu}), 0.86(\mathrm{~s}, 18 \mathrm{H}, \mathrm{tBu})$, $5.07\left(\mathrm{~s}, 4 \mathrm{H}, \mathrm{Ar}-\mathrm{OCH}_{2} \mathrm{Ph}\right), 5.12$ (s, $\left.4 \mathrm{H}, \mathrm{Ar}-\mathrm{OCH}_{2} \mathrm{Py}\right), 6.90$ (d, $J=$ $\left.5.5 \mathrm{~Hz}, 4 \mathrm{H}, \mathrm{Py}-H_{3,5}\right), 6.94$ (d, $\left.J=7.4 \mathrm{~Hz}, 4 \mathrm{H}, \mathrm{Ph}-H\right), 7.04(\mathrm{t}, J=$ $7.6 \mathrm{~Hz}, 4 \mathrm{H}, \mathrm{Ph}-H), 7.10(\mathrm{~s}, 4 \mathrm{H}, \mathrm{Ar}-H), 7.12(\mathrm{~s}, 4 \mathrm{H}, \mathrm{Ar}-H)$, $7.13-7.18(\mathrm{~m}, 2 \mathrm{H}, \mathrm{Ph}-H)$ and $8.40\left(\mathrm{~d}, J=5.8 \mathrm{~Hz}, 4 \mathrm{H}, \mathrm{Py}-H_{2,6}\right)$ ppm. ${ }^{13} \mathrm{C}$ NMR $\left(100 \mathrm{MHz}, \mathrm{CDCl}_{3}\right) \delta=30.70,30.73,33.86$, $33.89,69.10,70.80,121.80,126.90,127.14,128.03,128.26$, $128.75,129.11,137.35,146.39,146.50,146.71,149.38,155.97$ and $156.72 \mathrm{ppm}$. FABMS: $m / z: 1083.45\left(\mathbf{M}^{+}\right)$.

\section{Extraction experiments and stoichiometry of metal complexation}

Metal picrates $\left(4.0 \times 10^{-5} \mathrm{M}\right)$ were prepared in situ by dissolving the metal hydroxide $(0.02 \mathrm{~mol})$ in $4.0 \times 10^{-5} \mathrm{M}$ picric acid $(1000 \mathrm{~mL})$; triply distilled water was used for all aqueous solutions. Two-phase solvent extraction was carried out between aqueous picrates $(10 \mathrm{~mL}$, [metal picrate $\left.]=4.0 \times 10^{-5} \mathrm{M}\right)$ and host $\left(10 \mathrm{~mL}\right.$, [host] $=4 \times 10^{-5} \mathrm{M}$ in $\left.\mathrm{CH}_{2} \mathrm{Cl}_{2}\right)$. The two-phase mixture in a stoppered flask was immersed in a thermostated water bath at $25{ }^{\circ} \mathrm{C}$ which was shaken at 300 strokes per min for $4 \mathrm{~h}$ and then kept at the same temperature for $1 \mathrm{~h}$, allowing the complete separation of the two phases. This was repeated 3 times. The absorbance of each solution was determined by UV spectroscopy $(\lambda=356 \mathrm{~nm})$. The method of continuous variation was employed to determine the stoichiometry in the complexes involving the host receptors 2,3 or 4 . The molar ratios of both the host and metal picrate were varied from 0 to 1 , while the total concentration was kept at several constant levels. Job plots were generated by plotting the extracted $\left[\mathrm{M}^{+}\right]$ versus the mole fraction of metal. We confirmed that this period was sufficient to attain the distribution equilibrium. The extractability was determined spectrophotochemically from the decrease in the absorbance of the picrate ion in the aqueous phase, as described by Pedersen. ${ }^{19}$

\section{${ }^{1} \mathrm{H}-\mathrm{NMR}$ complexation experiments}

To a $\mathrm{CDCl}_{3}-\mathrm{CH}_{3} \mathrm{CN}(10: 1, \mathrm{v} / \mathrm{v})$ solution $\left(5 \times 10^{-3} \mathrm{M}\right)$ of 2,3 or 4 in an NMR tube was added a $\mathrm{CD}_{3} \mathrm{CN}$ solution $\left(5 \times 10^{-3} \mathrm{M}\right)$ of $\mathrm{AgClO}_{4}$. The spectra were recorded after the additions. The temperature of the NMR probe was kept constant at $27^{\circ} \mathrm{C}$. The ${ }^{1} \mathrm{H}$ NMR data of the most-representative complexes are given below:

2: ${ }^{1} \mathrm{H}$ NMR (300 MHz, $\left.\mathrm{CHCl}_{3}-\mathrm{CH}_{3} \mathrm{CN}, 10: 1, \mathrm{v} / \mathrm{v}\right): \delta=0.83(\mathrm{~s}$, $18 \mathrm{H}, \mathrm{tBu}), 0.85(\mathrm{~s}, 18 \mathrm{H}, \mathrm{tBu}), 5.07\left(\mathrm{~s}, 4 \mathrm{H}, \mathrm{CH}_{2}-\mathrm{Ph}\right), 5.19(\mathrm{~s}, 4 \mathrm{H}$, $\left.\mathrm{CH}_{2}-\mathrm{Py}\right), 6.67\left(\mathrm{~d}, J=7.8 \mathrm{~Hz}, 2 \mathrm{H}, \mathrm{Py}-H_{3}\right), 6.94(\mathrm{~d}, J=7.6 \mathrm{~Hz}, 4 \mathrm{H}$, $\mathrm{Ph}-H$ ), 7.03 (t, $J=6.6 \mathrm{~Hz}, 6 \mathrm{H}, \mathrm{Ph}-H), 7.10$ (s, 4H, Ar-H), 7.13 $(\mathrm{s}, 4 \mathrm{H}, \mathrm{Ar}-H), 7.36\left(\mathrm{t}, J=7.8 \mathrm{~Hz}, 4 \mathrm{H}, \mathrm{Py}-H_{4,5}\right)$ and $8.49(\mathrm{~d}, J=$ $\left.4.7 \mathrm{~Hz}, 2 \mathrm{H}, \mathrm{Py}-H_{6}\right) \mathrm{ppm}$.

$2 \supset \mathbf{A g}^{+}:{ }^{1} \mathrm{H}$ NMR $\left(300 \mathrm{MHz}, \mathrm{CHCl}_{3}-\mathrm{CH}_{3} \mathrm{CN}, 10: 1, \mathrm{v} / \mathrm{v}\right): \delta=$ 0.85 (s, 18H, tBu), 0.98 (s, 18H, tBu), 4.65 (s, 4H, $\left.\mathrm{CH}_{2}-\mathrm{Py}\right), 5.06$ (s, $\left.4 \mathrm{H}, C_{2}-\mathrm{Ph}\right), 6.98(\mathrm{~d}, J=7.5 \mathrm{~Hz}, 4 \mathrm{H}, \mathrm{Ph}-H), 7.10-7.14(\mathrm{~m}$, $4 \mathrm{H}, \mathrm{Ph}-H), 7.16$ (s, 4H, Ar- $H$ ), 7.21 (t, $J=6.6 \mathrm{~Hz}, 2 \mathrm{H}, \mathrm{Ph}-H)$, 
$7.26(\mathrm{~s}, 4 \mathrm{H}, \mathrm{Ar}-H), 7.50\left(\mathrm{~d}, J=7.8 \mathrm{~Hz}, 2 \mathrm{H}, \mathrm{Py}-H_{3}\right), 7.57(\mathrm{t}, J=$ $\left.5.7 \mathrm{~Hz}, 2 \mathrm{H}, \mathrm{Py}-H_{4}\right), 7.82-7.92\left(\mathrm{~m}, 2 \mathrm{H}, \mathrm{Py}-H_{5}\right)$ and $8.77(\mathrm{~d}, J=$ $\left.4.9 \mathrm{~Hz}, 2 \mathrm{H}, \mathrm{Py}-\mathrm{H}_{6}\right) \mathrm{ppm}$.

3: ${ }^{1} \mathrm{H}$ NMR (300 MHz, $\left.\mathrm{CHCl}_{3}-\mathrm{CH}_{3} \mathrm{CN}, 10: 1, \mathrm{v} / \mathrm{v}\right): \delta=0.85(\mathrm{~s}$, $18 \mathrm{H}, \mathrm{tBu}), 0.86(\mathrm{~s}, 18 \mathrm{H}, \mathrm{tBu}), 5.06\left(\mathrm{~s}, 4 \mathrm{H}, \mathrm{CH}_{2}-\mathrm{Ph}\right), 5.19(\mathrm{~s}, 4 \mathrm{H}$, $\left.\mathrm{CH}_{2}-\mathrm{Py}\right), 6.93$ (d, $\left.J=7.2 \mathrm{~Hz}, 4 \mathrm{H}, \mathrm{Ph}-H\right), 7.00-7.05(\mathrm{~m}, 6 \mathrm{H}$, $\mathrm{Ph}-H), 7.08(\mathrm{~s}, 4 \mathrm{H}, \operatorname{Ar}-H), 7.10(\mathrm{~s}, 4 \mathrm{H}, \operatorname{Ar}-H), 7.13(\mathrm{~m}, 2 \mathrm{H}$, $\left.\mathrm{Py}-H_{5}\right), 7.27$ (d, $\left.J=7.8 \mathrm{~Hz}, 2 \mathrm{H}, \mathrm{Py}-H_{4}\right), 8.20\left(\mathrm{~s}, 2 \mathrm{H}, \mathrm{Py}-H_{2}\right)$ and $8.46\left(\mathrm{~d}, J=3.9 \mathrm{~Hz}, 2 \mathrm{H}, \mathrm{Py}-H_{6}\right) \mathrm{ppm}$.

$3 \supset \mathrm{Ag}^{+}:{ }^{1} \mathrm{H}$ NMR $\left(300 \mathrm{MHz}, \mathrm{CHCl}_{3}-\mathrm{CH}_{3} \mathrm{CN}, 10: 1, \mathrm{v} / \mathrm{v}\right): \delta=$ 0.84 (s, 18H, tBu), 0.91 (s, 18H, tBu), 5.07 (s, 4H, $\left.\mathrm{CH}_{2}-\mathrm{Ph}\right), 5.19$ (s, 4H, $\left.\mathrm{CH}_{2}-\mathrm{Py}\right), 6.98$ (d, $\left.J=7.5 \mathrm{~Hz}, 4 \mathrm{H}, \mathrm{Ph}-H\right), 7.07$ (s, 4H, Ar-H), 7.08-7.12 (m, 4H, Ph-H), 7.17-7.20 (m, 2H, Ph-H), 7.21 (s, 4H, Ar-H), 7.52-7.57 (m, 2H, Py- $\left.H_{5}\right), 7.69$ (d, $J=7.9 \mathrm{~Hz}, 2 \mathrm{H}$, $\left.\mathrm{Py}-H_{4}\right), 7.82\left(\mathrm{~s}, 2 \mathrm{H}, \mathrm{Py}-H_{2}\right)$ and $8.55\left(\mathrm{~d}, J=5.1 \mathrm{~Hz}, 2 \mathrm{H}, \mathrm{Py}-H_{6}\right)$ ppm.

4: ${ }^{1} \mathrm{H}$ NMR (300 MHz, $\left.\mathrm{CHCl}_{3}-\mathrm{CH}_{3} \mathrm{CN}, 10: 1, \mathrm{v} / \mathrm{v}\right): \delta=0.84(\mathrm{~s}$, $18 \mathrm{H}, \mathrm{tBu}), 0.85$ (s, 18H, tBu), 5.07 (s, $\left.4 \mathrm{H}, \mathrm{CH}_{2}-\mathrm{Ph}\right), 5.13(\mathrm{~s}, 4 \mathrm{H}$, $\mathrm{CH}_{2}-\mathrm{Py}$ ), 6.91 (d, $J=5.5 \mathrm{~Hz}, 4 \mathrm{H}, \mathrm{Py}-\mathrm{H}_{3,5}$ ), 6.94 (d, $J=7.4 \mathrm{~Hz}$, $4 \mathrm{H}, \mathrm{Ph}-H$ ), $7.02-7.07$ (m, 4H, Ph-H), 7.11 (s, 4H, Ar-H), 7.13 (s, $4 \mathrm{H}, \mathrm{Ar}-H)$, 7.14-7.18 (m, $2 \mathrm{H}, \mathrm{Ph}-H)$ and $8.38(\mathrm{~d}, J=5.9 \mathrm{~Hz}, 4 \mathrm{H}$, Py $\left.-H_{2,6}\right)$ ppm.

$4 \supset \mathrm{Ag}^{+}:{ }^{1} \mathrm{H}$ NMR $\left(300 \mathrm{MHz}, \mathrm{CHCl}_{3}-\mathrm{CH}_{3} \mathrm{CN}, 10: 1, \mathrm{v} / \mathrm{v}\right): \delta=$ 0.86 (s, 18H, tBu), 0.91 (s, 18H, tBu), 5.11 (s, 4H, $\left.\mathrm{CH}_{2}-\mathrm{Ph}\right), 5.15$ (s, 4H, $\mathrm{CH}_{2}-\mathrm{Py}$ ), 6.94-6.99 (m, 4H, Py- $\left.H_{3,5}\right) 7.09$ (d, $J=7.3 \mathrm{~Hz}$, $2 \mathrm{H}, \mathrm{Ph}-H$ ), 7.13 (s, 4H, Ar-H), 7.16-7.21(m, 6H, Ph-H), 7.21 (s, $4 \mathrm{H}, \mathrm{Ar}-H)$ and $8.32\left(\mathrm{~d}, J=6.0 \mathrm{~Hz}, 4 \mathrm{H}, \mathrm{Py}-H_{2,6}\right) \mathrm{ppm}$.

\section{Crystallographic analyses of 3}

Diffraction data were collected on a Bruker APEX 2 CCD diffractometer equipped with graphite-monochromated Mo-K $\alpha$ radiation at $150(2) \mathrm{K}^{20}$ Data were corrected for Lorentz and polarisation effects and for absorption. ${ }^{20}$ The structures were solved by direct methods and refined by full-matrix least-squares methods, on $F^{2} \cdot{ }^{21} \mathrm{H}$ atoms were refined using a riding model except for those on hetero atoms in 3 which were freely refined.

Crystal data for 3. $\mathrm{C}_{66} \mathrm{H}_{70} \mathrm{~N}_{2} \mathrm{O}_{4} \mathrm{~S}_{4}, M=1083.48$. Orthorhombic, space group $P_{m n 2}, a=15.1668$ (6), $b=14.7772$ (7), $c=$ 12.7612 (6) ̊, $V=2860.1$ (2) $\AA^{3} . Z=2, D c=1.258 \mathrm{~g} \mathrm{~cm}^{-3}, F(000)$ $=1152, T=100 \mathrm{~K}, \mu(\mathrm{Mo}-\mathrm{K} \alpha)=0.17 \mathrm{~mm}^{-1}, \lambda(\mathrm{Mo}-\mathrm{K} \alpha)=0.6525 \AA$, colourless crystal of size $0.20 \times 0.20 \times 0.06 \mathrm{~mm}^{3}$. The total number of reflections measured, to $\theta_{\max }=30.3^{\circ}$, was 345676 of which 11331 were unique $\left(R_{\text {int }}=0.087\right) ; 10920$ were 'observed' with $I>2 \sigma(I)$. For the 'observed' data only, $R_{1}=$ 0.037 ; $\mathrm{w} R_{2}=0.101$ for all 11331 reflections and 400 parameters. Residual electron density within $\pm 0.48 \mathrm{e}^{-3}$.

Crystallographic data (excluding structure factors) for the structures in this paper have been deposited with the Cambridge Crystallographic Data Centre as supplementary publication numbers CCDC 245644 for $2^{6}$ and 1021161 for 3 , respectively.

\section{Acknowledgements}

Devices (Institute for Materials Chemistry and Engineering, Kyushu University)". We would like to thank the OTEC at Saga University and the International Cooperation Projects of Guizhou Province (no. 20137002), The Royal Society of Chemistry for financial support and the EPSRC for an overseas travel grant to C.R.

\section{Notes and references}

1 (a) N. Morohashi, F. Narumi, N. Iki, T. Hattori and S. Miyano, Chem. Rev., 2006, 106, 5291-5316; (b) R. Kumar, Y. O. Lee, V. Bhalla, M. Kumar and J. S. Kim, Chem. Soc. Rev., 2014, 43, 4824-4870.

2 (a) F. Arnaud-Neu, G. Barrett, S. J. Harris, M. Owens, M. A. McKervey, M.-J. Schwing-Weill and R. Schwinte, Inorg. Chem., 1993, 32, 2644-2650; (b) E. Ghidini, F. Ugozzoli, R. Ungaro, S. Harkema, A. Abu ElFadl and D. N. Reinhoudt, J. Am. Chem. Soc., 1990, 112, 6979-6985; (c) S. Shinkai, T. Otsuka, K. Fujimoto and T. Matsuda, Chem. Lett., 1990, 19, 835-838; (d) T. Tuntulani, P. Thavornyutikarn, S. Poompradub, N. Jaiboon, V. Ruangpornvisuti, N. Chaichit, Z. Asfari and J. Vicens, Tetrahedron, 2002, 58, 10277-10285.

3 (a) M. Kumar, N. Kumar and V. Bhalla, Org. Biomol. Chem., 2012, 10, 1769-1774; (b) S. N. Podyachev, N. E. Burmakina, V. V. Syakaev, S. N. Sudakova, W. D. Habicher and A. I. Konovalov, J. Inclusion Phenom. Macrocyclic Chem., 2011, 71, 161-168; (c) T. Kajiwara, N. Iki and M. Yamashita, Coord. Chem. Rev., 2007, 251, 1734-1746.

4 (a) F. Botha, J. Budka, V. Eigner, O. Hudeček, L. Vrzal, I. Císařová and P. Lhoták, Tetrahedron, 2014, 70, 477-483; (b) H. Zhao, J. Zhan, Z. Zou, F. Miao, H. Chen, L. Zhang, X. Cao, D. Tian and H. Li, RSC Adv., 2013, 3, 1029-1032; (c) F. Miao, J. Zhan, Z. Zou, D. Tian and H. Li, Tetrahedron, 2012, 68, 2409-2413.

5 (a) Calixarenes in the Nanoworld, ed. J. Vicens and J. Harrowfield, Springer, Berlin, 2007; (b) M. Kumar, A. Dhir and V. Bhalla, Eur. J. Org. Chem., 2009, 4534-4540.

6 T. Yamato, C. P. Casas, H. Yamamoto, M. R. J. Elsegood, S. H. Dale and C. Redshaw, J. Inclusion Phenom. Macrocyclic Chem., 2005, 54, 261-269.

7 P. G. Krishna, J. M. Gladis, U. Rambabu, T. P. Rao and G. R. K. Naidu, Talanta, 2004, 63, 541-546.

8 (a) A. Sap, B. Tabakci and A. Yilmaz, Tetrahedron, 2012, 68, 8739-8745; (b) S. Sayin, M. Yilmaz and M. Tavasli, Tetrahedron, 2011, 67, 3743-3753; (c) F. Ozcan, M. Ersoz and M. Yilmaz, Mater. Sci. Eng., C, 2009, 29, 2378-2383; (d) S. Bozkurt, E. Kocabas, M. Durmaz, M. Yilmaz and A. Sirit, J. Hazard. Mater., 2009, 165, 974-979.

9 (a) A. Yilmaz, S. Memon and M. Yilmaz, Tetrahedron, 2002, 58, 7735-7740; (b) M. Tabakci, S. Memon, M. Yilmaz and D. M. J. Roundhill, J. Inclusion Phenom. Macrocyclic Chem., 2003, 45, 265-270; (c) M. Bayrakci, S. Ertul, O. Sahin and M. Yilmaz, J. Inclusion Phenom. Macrocyclic Chem., 2009, 63, 241-247; (d) M. Tabakci, S. Memon and M. Yilmaz, Tetra(1) 5 5 0

\title{
0
}

\author{
This work was performed under the Cooperative Research
Program of "Network Joint Research Center for Materials and \\ This work was performed under the Cooperative Research
Program of "Network Joint Research Center for Materials and
}


hedron, 2007, 63, 6861-6686; (e) D. M. Roundhill and H. F. Koch, Chem. Soc. Rev., 2002, 31, 60-67.

10 C. Pérez-Casas, S. Rahman, N. Begum, Z. Xi and T. Yamato, J. Inclusion Phenom. Macrocyclic Chem., 2007, 60, 173-185.

11 (a) P. M. Marcos, F. A. Teixeira, M. A. P. Segurado, J. R. Ascensoc, R. J. Bernardino, P. J. Cragg, S. Michel, V. Hubscher-Bruder and F. Arnaud-Neuf, J. Phys. Org. Chem., 2013, 26, 295-305; (b) C. Bonaccorso, F. Nicoletta, V. Zito, G. Arena, D. Sciotto and C. Sgarlata, Supramol. Chem., 2013, 25, 615-625; (c) J. J. Colleran, B. S. Creaven, D. F. Donlon and J. McGinley, Dalton Trans., 2010, 39, 10928-10936; (d) M. Tabakci, S. Memon and M. Yilmaz, Tetrahedron, 2007, 63, 6861-6865.

12 (a) T. Yamato, M. Haraguchi, J.-I. Nishikawa, S. Ide and H. Tsuzuki, Can. J. Chem., 1998, 76, 989-996; (b) T. Yamato, M. Haraguchi and S. Ide, J. Chem. Soc., Perkin Trans. 1, 1998, 609-614; (c) T. Yamato, J. Inclusion Phenom. Macrocyclic Chem., 1998, 32, 195-207.

13 A. Ovsyannikov, M. N. Lang, S. Ferlay, S. E. Solovieva, I. S. Antipin, A. I. Konovalov, N. Kyritsakas and M. W. Hosseini, Dalton Trans., 2013, 42, 116-126.

14 (a) F. Vögtle, Cyclophane Chemistry, John Wiley \& Sons Ltd, 1993; (b) M. Tashiro and T. Yamato, J. Org. Chem., 1981, 46, 4556-4562; (c) M. Tashiro and T. Yamato, J. Org. Chem., 1983, 48, 1461-1468.

15 (a) X. L. Ni, C. C. Jin, X. K. Jiang, M. Takimoto, S. Rahman, X. Zeng, D. L. Hughes, C. Redshaw and T. Yamato, Org. Biomol. Chem., 2013, 11, 5435-5442; (b) J. L. Zhao, H. Tomiyasu, X. L. Ni, X. Zeng, M. R. J. Elsegood, C. Redshawd, S. Rahman, P. E. Georghiou and T. Yamato, New J. Chem., 2014, 38, 6041-6049.

16 S. Sayin, F. Ozcan and M. Yilmaz, Mater. Sci. Eng., C, 2013, 33, 2433-2439.
17 A. Sap, B. Tabakci and A. Yilmaz, Tetrahedron, 2012, 68, 1 8739-8745.

18 M. E. Losi, C. Amrhein and W. T. Frankenberger, Rev. Environ. Contam. Toxicol., 1994, 136, 91-121.

19 (a) C. J. Pedersen, J. Am. Chem. Soc., 1967, 89, 70177036; (b) C. J. Pedersen, J. Am. Chem. Soc., 1967, 89, 2495-2496; (c) C. J. Pedersen, J. Am. Chem. Soc., 1970, 92, 391-394.

20 SAINT and APEX 2 software for CCD diffractometers, Bruker AXS Inc., Madison, USA, 2008.

21 G. M. Sheldrick, Acta Crystallogr., Sect. A: Fundam. Crystallogr., 2008, 64, 112-122.

22 M. J. Frisch, G. W. Trucks, H. B. Schlegel, G. E. Scuseria, M. A. Robb, J. R. Cheeseman, G. Scalmani, V. Barone, B. Mennucci, G. A. Petersson, H. Nakatsuji, M. Caricato, X. Li, H. P. Hratchian, A. F. Izmaylov, J. Bloino, G. Zheng, J. L. Sonnenberg, M. Hada, M. Ehara, K. Toyota, R. Fukuda, J. Hasegawa, M. Ishida, T. Nakajima, Y. Honda, O. Kitao, H. Nakai, T. Vreven Jr., J. A. Montgomery, J. E. Peralta, F. Ogliaro, M. Bearpark, J. J. Heyd, E. Brothers, K. N. Kudin, V. N. Staroverov, T. Keith, R. Kobayashi, J. Normand, K. Raghavachari, A. Rendell, J. C. Burant, S. S. Iyengar, J. Tomasi, M. Cossi, N. Rega, J. M. Millam, M. Klene, J. E. Knox, J. B. Cross, V. Bakken, C. Adamo, J. Jaramillo, R. Gomperts, R. E. Stratmann, O. Yazyev, A. J. Austin, R. Cammi, C. Pomelli, J. W. Ochterski, R. L. Martin, K. Morokuma, V. G. Zakrzewski, G. A. Voth, P. Salvador, J. J. Dannenberg, S. Dapprich, A. D. Daniels, O. Farkas, J. B. Foresman, J. V. Ortiz, J. Cioslowski and D. J. Fox, Gaussian 09, Revision D.01, Gaussian, Inc., Wallingford CT, 2013.

23 H. A. Benesi and J. H. Hildebrand, J. Am. Chem. Soc., 1949, 71, 2703-2707. 